\title{
KORELASI POLA ASUH ORANGTUA SISWA DENGAN PERILAKU AGRESIF SISWA SMP DI KABUPATEN KEDIRI
}

\author{
Wahindha Lantip Putratama ${ }^{1}$, Sri Panca Setyawati ${ }^{2}$, Yuanita Dwi Krisphianti ${ }^{3}$ \\ Universitas Nusantara PGRI Kediri'1,2,3 \\ putratama138@gmail.com¹, ju.wahyu@gmail.com³
}

\begin{abstract}
ABSTRAK
Perilaku agresif adalah perilaku yang menunjukkan tindak kekerasan untuk menyakiti orang lain atau merusak suatu benda yang dilakukan secara fisik maupun verbal. Perilaku agresif secara fisik ditunjukkan dengan memukul, melempar, meludahi, meninju dan sebagainya. Sedangkan bentuk perilaku agresif verbal ditunjukkan dengan berkata kasar, mengumpat, menghina, mengejek, dan sebagainya. Pola asuh orangtua adalah interaksi orangtua dengan anak yang diekspresikan melalui sikap, ucapan, nilai-nilai yang ditanamkan dalam mengasuh dan memenuhi tumbuh kembang anak. Tujuan penelitian ini digunakan untuk mengetahui adakah korelasi antara pola asuh orangtua siswa dengan perilaku agresif siswa SMP di Kabupaten Kediri. Populasi penelitian berjumlah 298 siswa dan sampel penelitian berjumlah 44 siswa. Instrumen pengumpul data yang digunakan adalah angket pola asuh orangtua dan skala perilaku agresif . Hasil penelitian ini menunjukkan nilai sig $0.730>0.05$, yang memiliki arti bahwa tidak ada korelasi antara pola asuh orangtua siswa dengan perilaku agresif siswa SMP di Kabupaten Kediri. berdasarkan kesimpulan yang diperoleh, maka saran yang bisa diberikan adalah 1) perilaku agresif yang muncul pada diri siswa tidak selalu berkorelasi dengan pola asuh orangtua, 2) bagi peneliti selanjutnya diharapkan meneliti faktor-faktor lain yang kemungkinan ada korelasi dengan perilaku agresif siswa.
\end{abstract} Kata Kunci pola asuh orangtua,

perilaku agresif

Cara mengutip: Putratama, W.L., Setyawati, S.P., Krisphianti, Y.D. (2018) Korelasi Pola Asuh Orangtua Siswa dengan Perilaku Agresif Siswa SMP di Kabupaten Kediri. Jurnal Nusantara of Research, 5(2), 61-66.

\section{PENDAHULUAN}

Perilaku agresif menurut Baron\& Bryne (Saputra, 2012) adalah perilaku yang bertujuan melukai perasaan atau menyakiti. sedangkan menurut pendapat lain tentang perilaku agresif yang disampaikan oleh Supriyo (Azizah, 2013) adalah suatu cara yang digunakan untuk melawan dengan sangat kuat, yakni seperti berkelahi, melukai, menyerang, menghukum, bahkan menghilangkan nyawa individu lain. Dengan kata lain, perilaku agresif merupakan perilaku yang dimaksudkan untuk melukai individu atau merusak benda milik individu lain.

Perilaku agresif merupakan suatu perilaku secara fisik dan kalimat verbal yang ditunjukkan dengan tindak kekerasan untuk menyakiti orang atau merusak suatu benda. Perilaku agresif juga bisa diartikan sebagai perilaku yang cenderung menyerang terhadap sesuatu yang mengecewakan dari diri individu. Perilaku agresif sendiri, sering terjadi pada kalangan remaja awal, dimana pada masa itu terjadi perubahan fisik, psikis, dan sosial pada diri remaja. Perubahan yang dimaksudkan adalah berubah yang awalnya masa anak-anak menjadi masa remaja. Tentunya dalam masa perubahan ini sering timbul berbagai permasalahan yang terkait, sehingga seorang individu yang tidak bisa menyelesaikan 
masalahnya dengan baik maka akan timbul berbagai perilaku yang menyimpang, salah satunya adalah perilaku agresif.

Permasalahan dalam bentuk fisik, psikis, dan sosial yang dialami oleh remaja seharusnya dapat diselesaikan dengan baik oleh mereka. Tentunya diharapkan orangtua dan lingkungan ikut serta berperan positif dalam tumbuh kembang remaja. Akan tetapi, akan menjadi permasalahan ganda apabila orangtua dan lingkungan remaja tinggal kurang mendukung perkembangan mereka. Pada masa ini remaja bisa dibilang masih labil dalam pencarian jati diti, jadi mereka membutuhkan contoh tentang perilaku, sikap, maupun nilai untuk dapat dijadikan acuan dalam penemuan jati diri. Ketika mereka tidak mendapatkan lingkungan yang demikian, seringkali terjadi permasalah-permasalahan salah satunya perilaku menyimpang yang mengakibatkan mereka memiliki perilaku agresif, yakni menyakiti orang lain untuk kepuasan atau kepentingan mereka.

Orangtua memiliki peran yang sangat penting dalam menentukan perkembangan remaja. Bila orangtua mampu memberikan pola asuh yang baik dirumah dan menanamkan nilai-nilai yang sebagaimana harusnya, tentu saja pendidikan di sekolah akan lebih mudah untuk mereka tangkap dan kesempatan keberhasilan mereka juga jauh lebih tinggi. Namun, akan menjadi sebaliknya apabila orangtua gagal dalam melakukan pola asuh yang baik terhadap anaknya. Peran pola asuh orangtua juga sangat berpengaruh terhadap perilaku agresif anak, dimana anak ketika menginjak fase remaja harus mendapatkan pola asuh yang positif.

Euis (Jannah, 2012) menjelaskan tentang pola asuh yang merupakan serangkaian interaksi yang terjadi mendalam antara orangtua dan anak dalam mengarahkan anak-anak untuk memiliki kecakapan hidup. Selain itu, Khon Mu'tadin (Jannah, 2012) menyatakan bahwa pola asuh adalah interaksi antara anak dan orangtua selama mengadakan kegiatan pengasuhan yang berarti orangtua mendidik, membimbing dan mendisiplinkan serta melindungi anak sehingga memungkinkan anak untuk mencapai tugas-tugas perkembangannya.

Perilaku agresif yang terjadi pada siswa SMP berdasarkan hasil observasi yang dilakukan di SMPN 2 Papar Kediri, bahwa ditemukan siswa melakukan perilaku agresif verbal dan fisik. Bentuk dari perilaku agresif verbal berupa menghina, ketika ada teman yag mempunyai kekurangan misal ada teman yang tidak bisa mengerjakan soal yang diberikan guru ketika pelajaran berlangsung, teman-teman lain menghina dengan kata bodoh dan lambat, siswa mencela siswa lainnya dengan memanggil teman-temannya dengan nama orangtuanya, siswa berkata kasar ketika emosi marah muncul. Tidak saja perilaku agresif verbal tapi juga terdapat perilaku agresif fisik, seperti awalnya bercanda tapi disertai dengan pukulan, terjadi selisih paham sampai saling memukul, pengroyokan, dan tawuran dengan sekolah lain. Banyaknya perilaku agresif yang terjadi pada siswa SMP membuat penasaran tentang bagaimana pola asuh orangtua terhadap siswa yang berperilaku agresif.

Berdasarkan paparan yang telah dijelaskan di atas, maka peneliti melakukan penelitian tentang korelasi antara pola asuh orangtua dengan perilaku agresif siswa SMP di Kabupaten Kediri. Hasil dari penelitian tersebut akan dipaparkan dalam artikel ini. 


\section{METODE}

Pada penelitian ini pendekatan penelitian yang digunakan adalah pendekatan kuantitatif. Karena untuk bisa mendapat jawaban yag dibutuhkan diperlukan perhitungan yang menggunakan uji statistik yang nantinya menggunakan angka-angka. Menurut Sugiyono (2015), penelitian kuantitatif adalah pendekatan penelitian yang berlandaskan pada filsafat positivism, digunakan untuk meneliti pada populasi dan sampel tertentu. Filsafat positivism memandang realitas/gejala itu dapat diklasifikasikan relative, tetap, konkrit, teramati, terukur, dan hubungan gejala bersifat sebab akibat.

Teknik penelitian yang digunakan adalah teknik penelitian korelasional. Teknik penelitian merupakan suatu proses yang diperlukan dalam perencanaan dan pelaksanaan sebuah penelitian. Tujuan dari teknik penelitian korelasional adalah mengetahui korelasi antara pola asuh orangtua dengan perilaku agresif siswa SMP di Kabupaten Kediri.

Pelaksanaan dan pengolahan data hasil penelitian dilaksanakan selama satu bulan, yakni 2 minggu pada bulan Oktober dan 2 minggu pada bulan November. Penelitian dilaksanakan ditempat SMPN 2 Papar Kediri. Tempat pemilihan dipilih karena ada kerjasama dengan pihak sekolah untuk mengadakan peneltian dan yang paling utama adalah kondisi siswa, yakni terdapat perilaku agresif pada diri siswa SMPN 2 Papar Kediri.

Populasi dari penelitian ini adalah seluruh siswa SMP kelasn VIII, yang berjumlah 298 siswa. Adapun sampel penelitian yang merupakan sebagiian dari populasi yang diteliti adalah berjumlah 44 siswa. Sampel penelitian diambil dengan menggunakan teknik simple random sampling, yakni pengambilan anggota sampel dari populasi dilakukan secara acak tanpa memperhatikan strata yang ada dalam populasi itu. Pengambilan sampel dilakukan dengan berdasarkan pendapat Arikunto yang menyebutkan apabila subjek kurang dari 100 maka semuanya diambil dan digunakan sebagai sampel. Akan tetapi, jika subjek lebih dari 100 maka jumlah sampel dapat diambil $10-15 \%$ atau $20-25 \%$ atau lebih. Karena jumlah populasi adalah 298 siswa maka, peneliti mangembil $15 \%$ dari jumlah populasi yang digunakan sampel.

Prosedur pengumpulan data yang digunakan dalam penelitian ini adalah dengan cara menggunakan angket pola asuh orangtua dan skala perilaku agresif siswa. Model angket yang digunakan dalam penelitian ini adalah dengan menggunakan skala interval. Skala interval menunjukkan jarak antara satu data dengan data yang lain dan mempunyai bobot yang sama. Item-item dalam skala ini merupakan pernyataan dengan tiga pilihan jawaban yaitu a (mewakili otoriter), b (mewakili permisif), dan c (mewakili demokratis). Angket pola asuh orangtua dan skala perilaku agresif yang digunakan dalam pengumpulan data menggunakan pengukuran skala likert yang disajikan dalam pernyataan favourable dan unfavourable. Angket pola asuh orangtua dan skala perilaku agresif sebelum digunakan telah melalui proses uji validasi dan reliabilitas instrumen terlebih dahulu. Hal ini dilakukan untuk mendapatkan hasil yang sesuai maka perlu digunakan instrumen yang valid dan reliabel.

Adapun teknik analisa data yang digunakan adalah dengan menggunakan teknik korelasi pearson product moment. Cara yang digunakan untuk mengambil keputusan adalah 
jika nilai signifikansi > 0.05 maka tidak ada korelasi antara pola asuh orangtua dengan perilaku agresif siswa. tetapi, jika nilai signifikansi $<0.05$ maka ada hubungan korelasi antara pola asuh orangtua dengan perilaku agresif siswa.

HASIL

Setelah dilakukan penelitian, maka didapatlah hasil penelitian yang dijabarkan melalui grafik 1. tentang pola asuh orangtua siswa SMP dan Selanjutnya untuk gambaran prilaku agresif siswa dapat diamati pada grafik 2. tentang skor prilaku agresif. Pada bagian ini juga dipaparkan tentang hasil korelasi antara pola asuh orang tua siswa dan prilaku agresif siswa SMP yang dapat di amati pada table 1 .

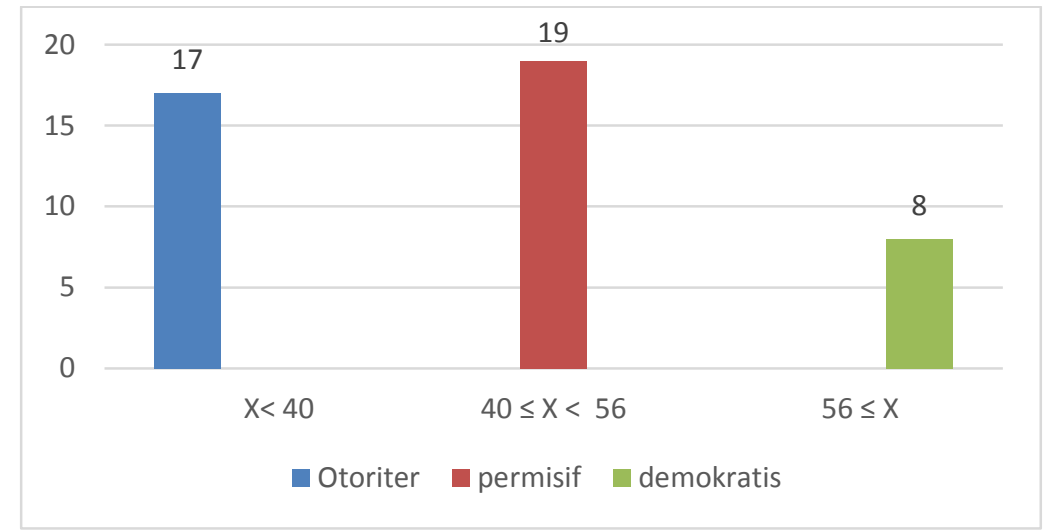

Grafik 1. Grafik pola asuh orangtua siswa SMP

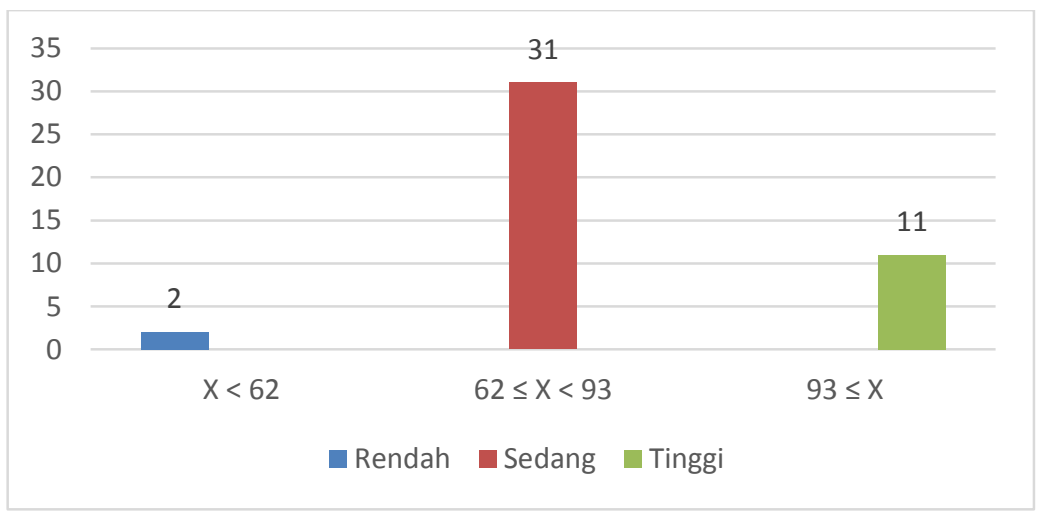

Grafik 2. Grafik skor perilaku agresif

Tabel 1. Tabel Hasil Analisis Korelasi

\begin{tabular}{llrr}
\hline & & Pola Asuh & Perilaku Agresif \\
\hline Pola Asuh & Pearson Correlation & 1 & .054 \\
\cline { 2 - 4 } & Sig. (2-tailed) & & .730 \\
\cline { 2 - 4 } & $\mathrm{N}$ & 44 & 44 \\
\hline Perilaku Agresif & Pearson Correlation & .054 & 1 \\
\cline { 2 - 4 } & Sig. (2-tailed) & .730 & 44 \\
\cline { 2 - 4 } & $\mathrm{N}$ & 44 & \\
\hline
\end{tabular}




\section{PEMBAHASAN}

Berdasarkan grafik 1.1 tentang pola asuh orangtua siswa SMP, menunjukkan bahwa pola asuh orangtua dengan interval $\mathrm{X}<40$ tergolong dalam pola asuh otoriter dengan nilai $18,18 \%$, interval $40 \leq X<56$ tergolong pola asuh permisif dengan nilai $43,18 \%$, interval $56 \leq X$ tergolong pola asuh demokratis dengan nilai 38,64\%. Berdasarkan hasil tersebut maka dapat disimpulkan mayoritas siswa SMP di kabupaten Kediri mempunyai pola asuh permisif. Yakni pola asuh yang membiarkan saja tumbuh kembang anak, tidak mengambil pusing, tidak atau kurang peduli, acuh tak acuh, tidak atau kurang memberi perhatian karena sibuk dengan tugastugas, menyerah pada keadaan, melepaskan tanpa kontrol, mengalah karena tidak mampu mengatasi keadaan, atau membiarkan anak karena kebodohan.

Berdasarkan grafik 1. 2 tentang skor perilaku agresfi, menunjukkan bahwa perilaku agresif siswa SMP dengan interval $X<62$ tergolong dalam perilaku agresif rendah dengan nilai $4.55 \%$, interval $62 \leq X<93$ tergolong perilaku agresif sedang dengan nilai $70,45 \%$, dan interval $93 \leq X$ tergolong perilaku agresif tinggi dengan nilai $25 \%$. Dari hasil penelitian dan pembahasan yang telah dikemukakan maka dapat disimpulkan mayoritas siswa SMP di Kabupaten Kediri mempunyai perilaku agresif sedang.

Berdasarkan tabel 1.1 tentang hasil analisa data yang menunjukkan nilai sig $0,730>0.05$. Dari tabel ini mengandung arti bahwa tidak ada korelasi antara pola asuh orangtua siswa dengan perilaku agresif siswa SMP. Jadi dari penelitian ini didapatkan sebuah hasil yang menunjukkan bahwa tidak ada korelasi antara ola asuh orangtua dengan perilaku agresif siswa.

Tinggi rendahnya perilau agresif yang terjadi di kelas VIII SMP Negeri 2 Papar Kediri tidak ada korelasinya dengan pola asuh orangtua. Hal ini terjadi diperkirakan karena perilaku agresif dipengaruhi oleh banyak faktor. Salah satu faktor yang menyebabkan seseorang melakukan perilaku agresi adalah adanya pengaruh kelompok (Sarwono, 2010) contonya konformitas teman sebaya. Menurut Santrok (Saputri, 2015), konformitas terjadi ketika individu meniru sikap atau tingkah laku orang lain dikarenakan tekanan yang nyata maupun yang dibayangkan mereka. Hal ini juga didukung oleh Baron dan Byrne (Saputri, 2015) yang mengungkapkan bahwa salah satu aspek yang menyebabkan seseorang melakukan perilaku agresi adalah adanya daya tarik ingroup yang akan mengakibatkan individu merasa memiliki kesamaan dengan sesama anggota (ingroup) kelompok dan cenderung melihat berbeda terhadap anggota kelompok lain (outgroup).

\section{KESIMPULAN DAN SARAN}

Berdasarkan hasil penelitian dan pembahasan yang telah dipaparkan maka diambil kesimpulan tidak ada korelasi antara pola asuh orangtua dengan perilaku agresif siswa SMP di Kabupaten Kediri. Saran yang dapat diberikan adalah ) perilaku agresif yang muncul pada diri siswa tidak selalu berkorelasi dengan pola asuh orangtua, 2) bagi peneliti selanjutnya diharapkan meneliti faktor-faktor lain yang kemungkinan ada korelasi dengan perilaku agresif siswa. 


\section{DAFTAR RUJUKAN}

Azizah, D.M. 2013. Mengurangi Perilaku Agresif Melalui Layanan Klasikal Menggunakan Teknik Sosiodrama Pada Siswa Kelas V Di SD Negeri Perigikan 03 KabupatenTegal. Skripsi, (Online), tersedia: http://lib.unnes.ac.iddiunduh 22 Oktober 2017.

Jannah, Husnatul. 2012. BentukPolaAsuh Orang Tua Dalam Menanamkan Perilaku Moral PadaAnakUsia Di Kecamatan Ampek Angkek. JurnalPesona PAUD, (Online), 1 (1): 3, tersedia: http://ejournal.unp.ac.id di unduh 11 Oktober 2017.

Saputra, Firman. 2012. Hubungan PolaAsuh Orang Tua Dengan Perilaku Agresif Pada Remaja Di SMA Gajah Mada Yogyakarta. NaskahPublikasi, (Online)., tersedia: http://digilib.unisayogya.ac.iddiunduh 26 September 2017.

Saputri, Y.A. 2015. Hubungan Antara Komformitas Dengan Perilaku Agresi Pada Remaja. NaskahPublikasi, (Online), tersedia: http:/leprints.ums.ac.iddiunduh 10 Desember 2017.

Sugiyono. 2015. Metode Penelitian Kuantitatif Kualitatif dan R\&D. Bandung: Alfabeta. 